\title{
Studying the Relationship Between Urban Green Corridors and Sustainable Urban Landscape
}

\author{
Sara Golestani Eraghi*, Mona Meschi, Saeed Gholampour \\ School of Architecture, College of Fine Arts, University of Tehran, Tehran, Iran \\ Email address: \\ sr.golestani@gmail.com (S. G. Eraghi), monameschi@gmail.com (M. Meschi), saeedgholampour65@gmail.com (S. Gholampour)
}

To cite this article:

Sara Golestani Eraghi, Mona Meschi, Saeed Gholampour. Studying the Relationship Between Urban Green Corridors and Sustainable Urban Landscape. International Journal of Science, Technology and Society. Special Issue: Research and Practice in Architecture and Urban Studies in Developing Countries. Vol. 3, No. 2-1, 2015, pp. 36-40. doi: 10.11648/j.jists.s.2015030201.18

\begin{abstract}
In the past, the concept of sustainability was a result of human knowledge about environment issues and cultural, economical and social problems. One of the main goals of sustainable development is to save the nature and to have a better look at it. The expression of sustainable development in urban spaces is named sustainable urban landscape. Architects have very important role in this matter since they are responsible for $75 \%$ of climate changing, directly or indirectly. Sustainable urban landscape is one of the effective factors in health of environment and reduction of environmental pollution. Green corridors are one of the most effective spaces in sustainability of urban landscapes. Green corridors involve long green spaces in the cities and river-valleys which flow among the cities and somehow change the micro climate of the areas. These spaces can have positive and negative effects on sustainability of urban landscape and then environmental health of cities. In this paper, we attempt to examine the role of green corridors in sustainability of urban landscape in means of increases and decreases of environmental pollutions. So that we will also have a case study of these spaces in one of the cities of Iran and we will try to represent some solutions to achieve sustainable urban landscape and environmental health.
\end{abstract}

Keywords: Environmental Health, Green Corridors, Urban Landscape, Sustainability

\section{Introduction}

Cities are the main economical base for the countries. They create jobs and services in themselves. The most of civilization and technological achievements occurred in cities and therefore, all of them are in line with the quality of life. On the other hand, industrial development and modernism has led to ecological and environmental problems which threaten public health and safety. From the point of researchers it can be the disincentive factor for economical development and quality of life.

In general, in sustainable development of cities plan, it is forecasted to observe some general principles: 1 . Cities should be livable for all the people 2 . They should present quality of life to people from all the social classes 3 . They should compete with each other and 4 . They should be managed properly.

One of the significant solutions is paying attention to environmental issues which affect the ecological sustainability of cities. And it seems to have global priority and also it is placed in green agenda. Protection of urban green spaces, making them and sustainable design, are placed at the subset.

Urban green corridors (or urban greenway corridors) are the most important urban green spaces which are made because of human interventions or they are penetrated from around into the cities. While conservation and development program differs for each case, but all of them have common points which are in relationship with sustainable development. So if we could find some designing or conserving principles for them we could have important steps in the way of sustainable cities for the future.

\section{What are Green Corridors?}

The origins of the green corridors planning approach, introduced with the purpose of preserving and providing the continuity of urban open spaces, are based on Olmsted's 'Parkways' concept in America and the Garden City concept of Ebenezer Howard during the twentieth century in England [1].

People have been setting aside greenways of various sorts 
for more than one hundred years. In North America in the late 19 th and early 20th centuries, parkways - early prototypes for greenways - were created to connect urban parks [2].

Since the middle of the last decade, some landscape architects have defined green corridors very expansively as "networks of linked landscape elements that provide ecological, recreational, and cultural benefits to the community" [3]. Although Fabos definite green corridors as:" Tunnels with various widths join to each other like the highways or railways"[4]. They are networks of linear elements that are planned, designed and managed for multiple purposes, including ecological, recreational, cultural, aesthetics or other purposes compatible with the concept of sustainable land use [5].

Landscapes and green corridors will increase the environment qualities and they are the best place for spending leisure times. Nowadays, although about $1 / 3$ up to $2 / 3$ of perspectives in the world contain green spaces and paths [6].

In the 1960s, citizens, ecological planners, and landscape architects recognized the need to protect waterways and other corridors that included a high concentration of important natural features [2].

Green corridors may be implemented in either rural or urban locations. They have been identified, also, for their function in helping to shape particular forms of urban design [7].

One of the examples of green corridors in urban spaces is river valleys. Urban river-valleys as one of urban ecological infrastructure could have effective role in order to create a balance between nature and the man-made spaces in city and the human relation to nature.

\section{Urban Sustainability and Green Corridors}

\subsection{What is Called Sustainable Urban Landscape}

The term sustainability refers to a community's capacity to support the long-term health and welfare of its natural and man-made environment, as well as all forms of life that depend on that environment. A sustainable community is focused not only on protecting natural resources, but also on ensuring a high quality of life for all residents. To achieve an increased level of sustainability, a community must recognize the interconnectedness of all things, as well as the impact their actions have on the greater region and the world. (6, Baraboo, Wisconsin)

Increasing recognition of the worlds' expanding population and current global rural to urban migration necessitates a better understanding and integration of urban ecological process into the framework for urban design. All the technological developments and human accommodation have led a lot of extra unused things in regions. During years this subjects disturb natural life cycles and chain of life in urban areas. Reinforcing the ecological networks in cities is a proposed solution for answering these problems, either for developing natural species or increasing mutual relations between human being and green spaces. Green ways can mix with urban networks for developing ecological activities and acting like natural city lungs [6]. Landscape sustainability can be achieved by ecological landscape planning which brings together the interactions of both the natural and cultural landscape structures [8].

\subsection{The Relationship Between Green Corridors and Sustainability}

According to definition of sustainable development, a sustainable city should contain essential characteristics of sustainability. Urban nature like green paths and corridors establish all the required sequence for life qualities, also this progression is the key part for sustainable development [6]. Thus, indicators of green corridors are "Providing green spaces, Pollutions and pollutants, Connectivity and continuity, Visions and Perspectives, Multi-functional structures, Tourism and income, Access ability and transportation, Social relationships". Those are used as factors to promote sustainable development in urban landscape.

Table 1. The features of green corridors in sustainability

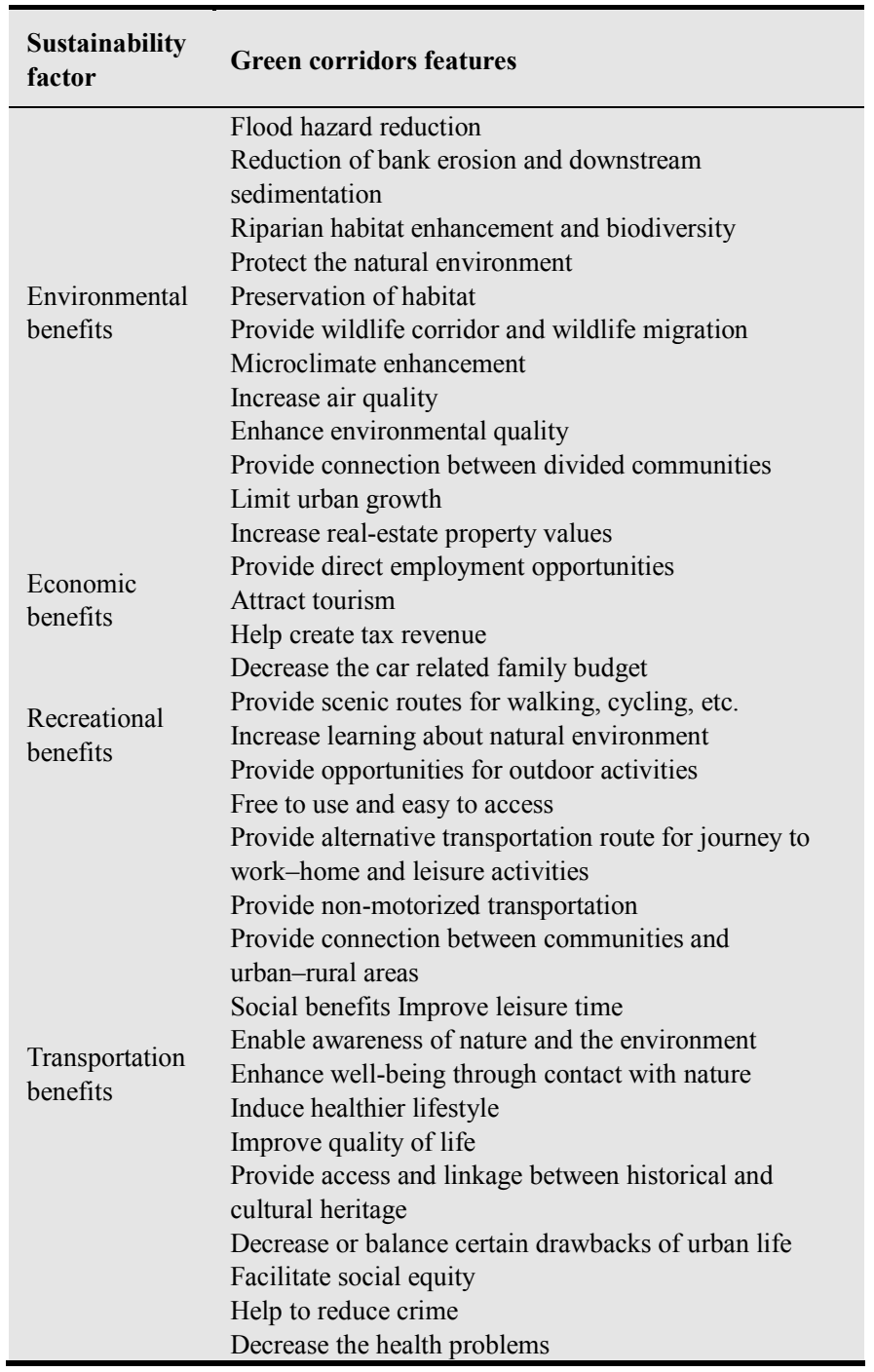


There are 4 main factors for sustainability that green corridors have some features in that subject, we brought them in table 1.

\section{Case Study: Darabad River-Valley}

One of the most important natural areas that bring life in urban spaces all over the world is a valley-river. In Tehran these river-valleys don't have a constructive role in increasing the spatial qualities and progressing the citizens' quality of life, they also cause different problems in the city.

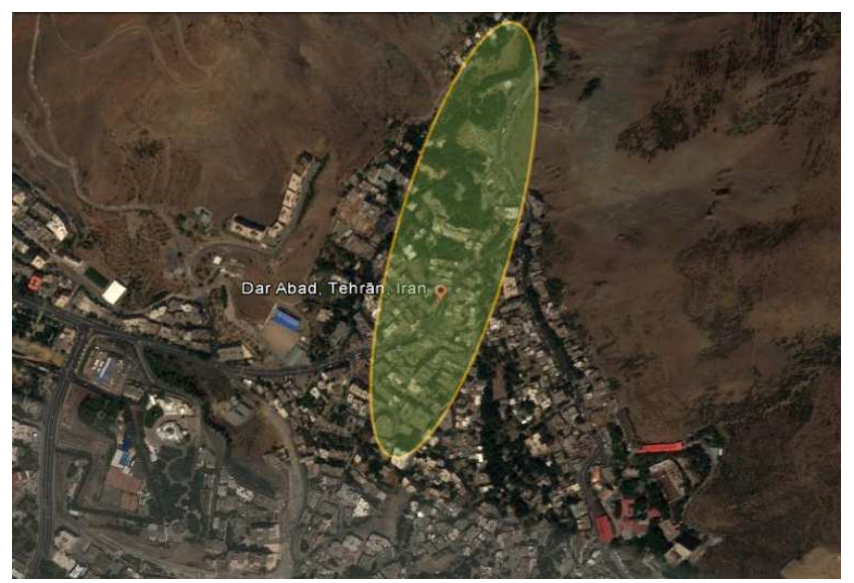

Figure 1. Darabad river-valley. Tehran. Iran.

Tehran have 9 valley-rivers one of them is Darabad that is situated in north-east of the city.

We chose Dar-Abad because of these reasons:

-remaining original and intact during the time

-variation in plants and animals

-green spaces in river- margin with historical background.

-crossing the river among the rural part and spread to the city

These are the benefits of Dar-Abad valley-rivers:

1 -fresh water resources

2-natural corridors of weather circulation.

3-create tourism space

4-creat green space and filtering the pollutions

5 -Increasing the quality of urban spaces.

Based on the factors for sustainable design and the context of the case-study as a urban river-valley, we suggest some design solutions for this case study based on its status.

As it can be seen in sketch 1 the route which water passes has a special topography which designer can use to have divers in water show which is led to Connection to and expression of temporality and time.

Providing visual access to green corridor can be done with the solution which is presented in sketch 2 and 4 .for example colonnade of trees which exists around the river at the entry of the river into the city, can help emphasizing on visual access.

By Design compatible with the topography (gradient, different levels and etc.) designer can respond to topography which is one of the solutions for sustainable design

In order to achieving sustainable landscape design, In sketch 3, some solutions like Using human scale and forms, Design compatible with the topography, Providing visual access to green corridor and Creating privacy and another facilities such as making green roofs at top of the buildings which exist around the river in the city, is provided.

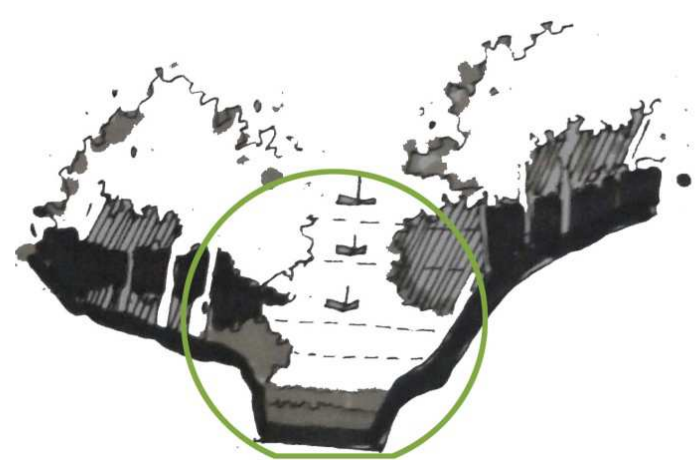

Figure 2. Sketch number 1.

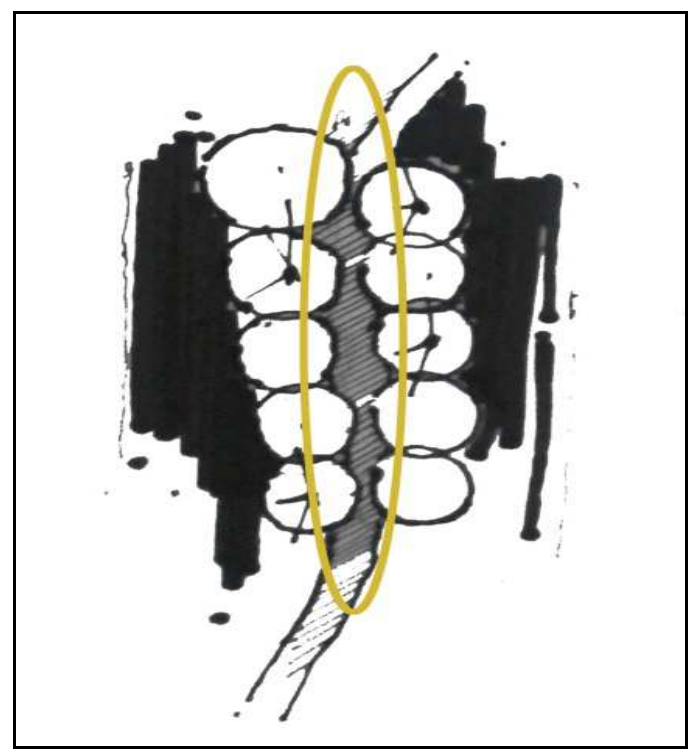

Figure 3. Sketch number 2.

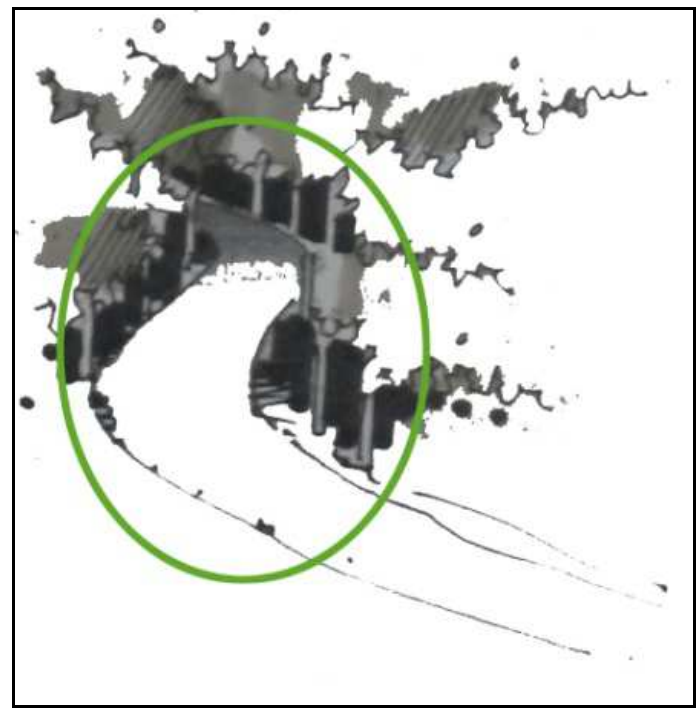

Figure 4. Sketch number 3. 


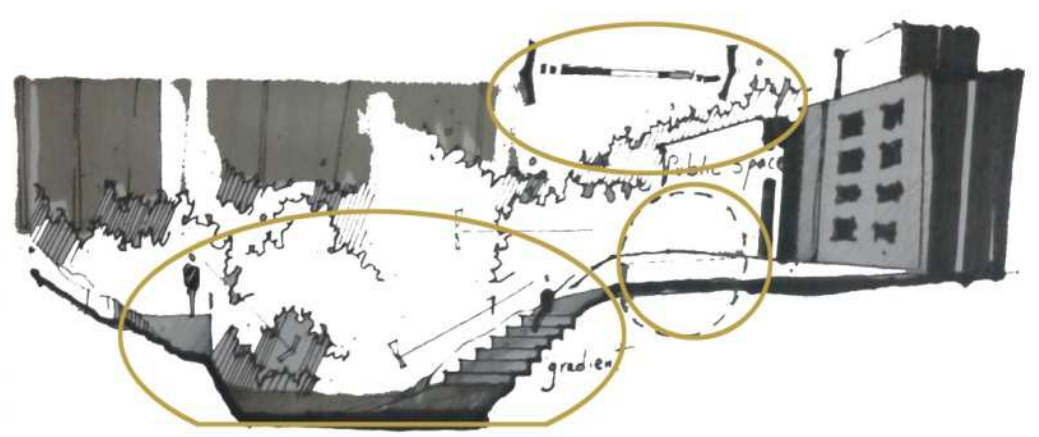

Figure 5. Sketch number 4

\section{Results, Discussion and Conclusion}

According to the relationship between green corridors and sustainability, some design solutions should be provided especially for landscape designers in order to achieve sustainable landscape design process for greenway corridors.
Following table shows us some of the most important design solutions provided by Hellmund and Smith in left column, in relationship with possible design objectives which are concluded by this article's authors in right column:

Table 2. The features of green corridors in sustainability

\begin{tabular}{|c|c|}
\hline Possible design objectives applicable to greenway design & Landscape design solutions \\
\hline $\begin{array}{l}\text { Provide visual and physical access to greenway elements that express } \\
\text { seasonality (e.g., leaf color, frozen water, fruit). }\end{array}$ & Using different deciduous trees and different shapes of water show \\
\hline $\begin{array}{l}\text { Cleanse stormwater and other waste outputs from adjacent land uses } \\
\text { before or as they enter the greenway. }\end{array}$ & Providing appropriate infrastructure for wastewater \\
\hline Feature significant topography in the greenway. & Designing gradient, different levels, $\ldots$ \\
\hline Provide equal access to the greenway to all segments of the community. & $\begin{array}{l}\text { Using the green corridor to Provide different facilities for various social groups } \\
\text { (public space, open space, calm space, ...) }\end{array}$ \\
\hline Engage future greenway users in the green corridor design process. & Implanting fruit plants and vegetables by users \\
\hline $\begin{array}{l}\text { Use the greenway to provide visual and physical access ("connectedness") } \\
\text { to nature. }\end{array}$ & $\begin{array}{l}\text { Creating spaces with flexible materials such as sand that could be changed by } \\
\text { users }\end{array}$ \\
\hline $\begin{array}{l}\text { Use local solutions whenever possible in implementing aspects of the } \\
\text { greenway. }\end{array}$ & Using from indigenous, minimal and simple material in design \\
\hline $\begin{array}{l}\text { Create vantage points within and adjacent to the greenway where users can } \\
\text { view wildlife, other greenway users, or interesting elements. }\end{array}$ & Creating privacy and another facilities such as pergola with herbal elements \\
\hline $\begin{array}{l}\text { Whenever possible or appropriate, extend greenway functions outward } \\
\text { from the greenway to integrate the greenway and its context. }\end{array}$ & Dragging around public spaces into green corridors \\
\hline $\begin{array}{l}\text { Create transition areas (vestibules) for users coming into the greenway to } \\
\text { help them realize and remember that they are entering a special place } \\
\text { where appropriate behaviour may differ from where they are coming. }\end{array}$ & $\begin{array}{l}\text { Emphasizing on green corridors in order to experience and realize different } \\
\text { space with narrow path }\end{array}$ \\
\hline $\begin{array}{l}\text { Seek out post-industrial or other "denatured" areas in selecting greenway } \\
\text { alignments if they are compatible with greenway objectives, and don't } \\
\text { Attempt to totally obscure their previous uses, pretending they were } \\
\text { pristine areas. }\end{array}$ & not deleting the existing and remaining elements in design and use them \\
\hline $\begin{array}{l}\text { Create elements along the greenway that remind users they are in the } \\
\text { greenway and that give more information about the greenway's functions. }\end{array}$ & Using green corridors 's plant and materials for designing the details \\
\hline $\begin{array}{l}\text { Make obvious the human interventions in the greenway, instead of trying } \\
\text { to obscure these, giving cues to care. }\end{array}$ & not deleting people's interference during the time from green corridors \\
\hline $\begin{array}{l}\text { Include obvious places (e.g., trails and viewing blinds) for people in the } \\
\text { greenway, as appropriate. }\end{array}$ & Using human scale and forms and the audience clearly be seen in the design \\
\hline $\begin{array}{l}\text { Use local materials in any construction (paths, bridges, etc.) within the } \\
\text { greenway to emphasize what is unique to an area and gives an area its } \\
\text { specific sense of place. }\end{array}$ & Using dried plants, stones or wasted industrial materials within the corridor \\
\hline $\begin{array}{l}\text { Seek out post-industrial or other "denatured" areas in selecting greenway } \\
\text { alignments if they are compatible with greenway objectives, and don't } \\
\text { attempt to totally obscure their previous uses, pretending they were } \\
\text { pristine areas. }\end{array}$ & $\begin{array}{l}\text { Using waste material and abandoned area in design.try to converting abandoned } \\
\text { area to public space or play grounds around the green corridors }\end{array}$ \\
\hline $\begin{array}{l}\text { Delineate the edges of or entrances to greenways so visitors know the } \\
\text { rules are different within. }\end{array}$ & $\begin{array}{l}\text { Making difference between considered usages in corridor and usages out of } \\
\text { corridor }\end{array}$ \\
\hline $\begin{array}{l}\text { Use local materials in any construction (paths, bridges, etc.) within the } \\
\text { greenway to emphasize what is unique to an area and gives an area its } \\
\text { specific sense of place. }\end{array}$ & $\begin{array}{l}\text { Using organic material and forms in designing like some stones or waste } \\
\text { materials around or dried plants. }\end{array}$ \\
\hline
\end{tabular}




\section{References}

[1] A.Toccolini, N.Fumagalli \& G.Senes, Greenways planning in Italy: the Lambro river valley greenways system, Landscape and Urban Planning, 76, pp. 98-111, 2006.

[2] P. Hellmund \& D.Smith, Designing Greenways, 2006 Island Press, Washington.

[3] F.Ndubisi, D.M.Terry, D.D.Niels, Environmentally sensitive areas: a template for developing greenway corridors. In: J.Fabos, J.Ahern (Eds.), Greenways: The Beginning of an International Movement, 1995, Elsevier, Amsterdam.

[4] Fabos, J.G, Greenway planning in the United States: its origins and recent case studies, Landscape and Urban Planning, 68, pp. 321-342, 2004.

[5] J.Ahern, Greenways as a planning strategy. In: Fabos, J.,Ahern, J. (Eds.), Greenways: The Beginning of an International Movement., pp. 131-156, 1995, Elsevier, Amsterdam.

[6] F.Shahani, The Role of Green Way in the Achievement of Urban Sustainable Development (District 3 of Tehran as a Case Study), World Applied Sciences Journal 19 (10): 1514-1522, 2012.

[7] D.Groome" Green corridors": a discussion of a planning concept, landscape and urban planning. 19(1990),pp. 383-387.Elsevier,Amesterdam.

[8] S.Beatriz Pena, M.Abreu, R.Teles, M.Espírito-Santo, $A$ methodology for creating greenways through multidisciplinary sustainable .landscape planning. Journal of Environmental Management 91 (2010), pp.970-983.elsevier

[9] Fabos, J., (1995). Introduction and overview: the greenway movement, uses and potential of greenways. In: Fabos, J., Ahern, J. (Eds.), Greenways: The Beginning of an International Movement. Elsevier, Amsterdam, pp. 1-14. 